\title{
Occupational and Environmental Cancer
}

\section{Saeed Yari ${ }^{1}$, Ayda Falah-Asadi², Mohammad Nourmohammadi ${ }^{3}$}

${ }^{1}$ School of Health Science, Shahid Beheshti University of Medical Sciences, Tehran, Iran. ${ }^{2}$ School of Nursing and Midwifery, Ghazvin University of Medical Sciences, Ghazvin, Iran. Corresponding author. ${ }^{3}$ Associate Professor of Occupational Health Engineering Department, Health College, Mashhad University of Medical Sciences, Mashhad,Iran

\begin{abstract}
Environmental pollution is one of the main causes of disease, death, and disability worldwide. International Labor Organization (ILO) estimates mortality caused by occupational cancer worldwide to be two times higher than occupational accidents. Approximately, 10 important risk factors account for $85 \%$ of all occupational cancers. Factors for occupational cancer includes Asbestos, chemicals such as aniline, chromates, dinitrotoluene, arsenic and its inorganic compounds, beryllium and its compounds, cadmium and nickel compounds, wood dust, crystalline silica, brown coal phosphors, furnace emissions, pollution caused by diesel equipment, Nano-Materials, biological agents, ionizing radiation and non-ionizing radiation, thermal shock, shift work, stress and work while sitting. Also some other environmental factors can cause cancer which concludes air, water and soil pollutions, smoking, sunlight, radon gas, electromagnetic fields, agriculture, behavior and lifestyle (such as alcohol and tobacco consumption, diet, sleep patterns, personal habits and social and cultural environment behaviors). More than $75 \%$ of mortality due to cancer can be avoided via controlling occupational and environmental risk factors. Most of cancers are not hereditary and caused by occupational and environmental biological agents, and are potentially preventable. So, it is recommended that more researches should be performed in this field in order to detect more scientific and effective methods to detect number and type of cancers due to occupational and environmental factors.
\end{abstract}

Keywords: Occupational cancer- environmental cancer- cancer risk factors- cancer prevention

Asian Pac J Environment and Cancer, 1 (1), 5-13

\section{Introduction}

Although some of natural activities (volcano, fire, so on) may result to different pollutions to be distributed in environment, human activities is the most critical cause of air pollution [1]. Dangerous chemicals can be randomly distributed in the environment, but a wider range of air pollutants could be released in industrial areas and due to other activities that can harm human health and environment [2]. Air pollution can increase mortality or cause serious diseases with a potential danger for human health [3]. So, environmental pollution is one important cause of disease, death, and disability worldwide [4]. So that, WHO introduces air pollution to be responsible for almost 7 million mortality in the last year [5]. Cancer is the second main cause of mortality worldwide, and after cardiovascular diseases [6-7]; So that, in 2000, approximately 10.1 million peoples were estimated to be
Submission Date: 06/15/2018Ａcceptance Date: 08/19/2018

affected by it and it is predicted that this rate will reach to 15 million peoples in 2020. Prevalence rate of cancer between years 2000 to 2020 will be approximately three times higher than past, and this rate will be two times higher to 2030 [8-9]. International Labor Organization (ILO) estimates mortality due to occupational cancer worldwide to be two times higher than occupational accidents [10].

"Cancer" is a word for diseases in which cells will be divided in an abnormal and uncontrolled manner. There are a number of well-known conditions that undoubtedly show a correlation between some occupational exposures and some types of cancer [11]. On the other hand, cancer epidemics is one of the most important problems of general health worldwide [10], and due to problems in proving causality, and the time between occupational exposure and cancer, there is no available information about the actual rate of occupational cancer [12].

Corresponding Author:

Dr. Ayda Falah-Asadi

School of Nursing and Midwifery, Ghazvin University of Medical Sciences, Ghazvin, Iran.

Email: ASydaFA@gmail.com 
Nowadays, Information of estimation of human health and environmental risks are incomplete for more than 10,000 existing chemical compounds, and hundreds of other compounds will be added to this amount annually. Also, the potential of most commercially used materials is not quantified for human exposure [13-14]. Moreover, there are many chemicals which were categorized as harmless or cause of few harms for human health, and after evaluation of risk and doing related tests were recognized to be oncogene (such as asbestos), and/or reproductive disorders (such as thalidomide) [13]. Now, 202 factors have introduced by International Agency for Research on Cancer to be certainly or most probably oncogenes (groups 1 and 2a), and 302 other factors are categorized to be human possible oncogenes (group b2) [15]. A big part of these factors such as cigarette smoke is presented in the daily work or living places [16]. Figure 1 shows the worldwide mortality rate due to cancer (except skin cancer besides melanoma) based on the Age-Standardized Rate (ASR) [17]. The figure indicates that about 48,000 cancer cases per year are detected in the United States, about $4-10 \%$ of all cancers in the United States and now in the EU account for $53 \%$ of all deaths associated with occupational cancer [18]. It is estimated that $19 \%$ of worldwide cancer cases are related to environment or occupation that is equal to 1.3 million deaths per year [19]. Previous estimations of ILO regarding occupational cancers show that $32 \%$ of worldwide mortality happens due to occupational cancer [20]. Approximately 1.5 million workers in Australia are potent to have oncogenes exposure [21]. Lung cancer, mesothelioma, leukemia and bladder cancer are some of the most common types of occupational cancers [22-23]. One out of ten cases of lung is a result of occupational exposures [24]. Until recently, cancer was a disease in western and industrial countries, though, in $2008,56 \%$ of new cases ( 7.1 million) and $63 \%$ of total cancer deaths (4.8 million) were reported to occur in low-income and middle-income countries (LMICs) [12-25]. Cancer in many Asian countries is a serious health threat and is the major cause of death in Asia and the Pacific, such as Japan and Korea [26]. Detected cancers in Asia are respectively related to lung, breast, colon, and rectum, and the main cause of death are cancers of lung, stomach, and liver [24, 26-27]. In 2000, there were more than 3 million new cases of cancer and more than 2 million cancer deaths in Asia, and it is predicted that if current management and protective strategies remain unchanged, new detected cases in Asia will arise to 1.7 million cases to 2020 [26]. In the study of Paolo and colleagues that performed to assess cancer among middle and lower middle-income countries (LMICs), and high-income countries (HICs), it became clear that the factor of infection in both groups is decreased, the nutrition and hormone factors in both groups are increased, and job, smoking and alcohol factors in LMICs are increasing, unlike HICs [28].

\section{Occupational cancers}

In the eighteenth century, Percivall Pott was the first one to describe occupational cancer, and by the 1970s,

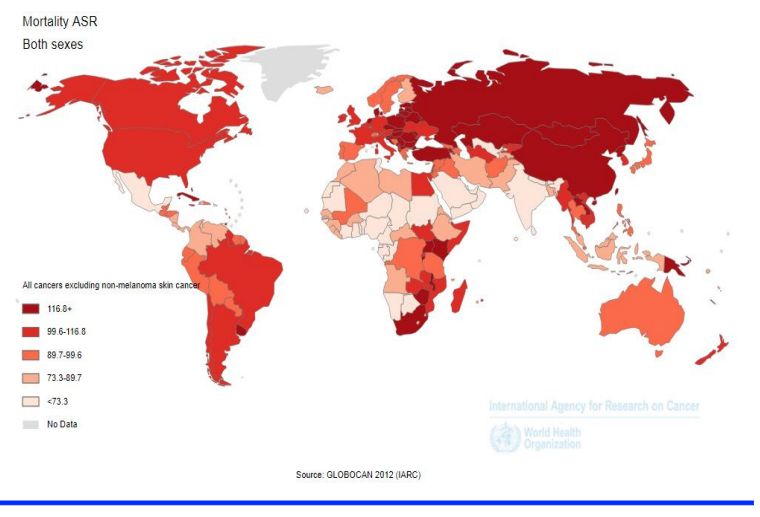

Figure 1. Worldwide Mortality Due to Cancer (Except Skin Cancer Besides Melanoma) Based on Age-Standardized Rate (ASR)

most known oncogenes in the workplaces were found [29-30]. Occupational cancers are rapidly increasing worldwide [18]. Occupational cancer is related to exposure to factors such as chemicals, dust, radiation, and some industrial processes [31-32]. Exposure to chemical oncogenes can cause mutations that result to cells to become out of control and cause cancer [33-34]. Mortality due to cancer and occupational cancer has increased because of an increase in life expectancy and a gradual reduction in other causes of death, such as infectious diseases and injuries [8-25]. Ten major risk factors for occupational oncogenesis is responsible for around $85 \%$ of all occupational cancers. [10]. Oncogenic agents in the workplace may include chemicals such as anilines, chromates, dinitrotoluene, arsenic and its inorganic compounds, beryllium and its compounds, cadmium and nickel compounds, wood dust, asbestos, crystalline silica, brown coal phosphors, smoke of furnaces, pollution of diesel instruments, cigarette smoke, sunlight, radon gas, and ionizing and non-ionizing radiation [19, 31, 35-37]. Some of the chemicals used in paint, rubber, and other chemical industries are all related to bladder cancer. Fortunately, these chemicals are now banned [38-39]. Some industrial processes that are related to cancer includes the production of aluminum, iron and steel and underground mines that may cause cancer by exposure to uranium or radon [40]. Also, the shift work, which can disrupt the daily rhythm, is recognized as a risk factor for different types of cancer, especially breast cancer [41-43]. Table 1 shows different types of occupational cancers and risk factors, which develop them in different industries [24, 44-54].

\section{Asbestos}

Asbestos is a natural mineral that can damage the lungs [55]. According to survey, nine out of ten people with mesothelioma have been exposed to asbestos [38]. People who work in industries such as shipbuilding and construction may contact asbestos [31-55]. Since June 1, 2005, the use of asbestos was banned in Europe [56]. Lung cancer is responsible for 54 to 75 percent of all occupational cancers. Epidemiological studies show that exposure to occupational risk factors can result to 
$8.4 \%$ to $5.3 \%$ of all cancers, as well as 17 to $29 \%$ of total mortality among men due to lung cancer. Asbestos is the cause of $55-85 \%$ of lung cancers, which could be prevented previously [10]. Asbestos in 2004 caused the death of 59,000 cases of mesothelioma [57]. Figure 2 shows environmental and occupational risk factors [58].

\section{Chemicals}

Different chemicals have different toxicities [13]. Overexposure to these materials in the workplace can lead to various illnesses [32]. Also, chemicals or their compounds can cause cancer in high risk people [13]. These materials can be classified as oncogene by scientists. The most important organizations in this field are the International Agency for Research on Cancer (IARC) and the World Health Organization [59]. Chemicals are known causes of occupational cancers [38]. In a limited number of studies, the correlation between chemical exposure and cancer has been thoroughly investigated, and many studies also should be done to assess other hazards, such as physical, pharmaceutical and biological factors [59]. Scientists have proved the association between exposure to endocrine disrupting compounds (EDCs) and the increased incidence of certain cancers such as breast, endometrial, ovarian, testicular, prostate, and thyroid cancers, which have increased during last 40-50 years [60]. The authors mention that exposure to pesticides, some of biphenyl polyphenols (PCBs), and arsenic are the cause of prostate cancer [59, 61-62]. In 2004, exposure to leukaemogens (including benzene, ethylene oxide and ionizing radiation) approximately caused 7,400 deaths due to leukemia [57].

Solid circles (exposure sources) indicate human carcinogens; Dotted circles indicate human probable carcinogens. Hubs, ETS (environmental tobacco smoking), steel founding, asbestos, PAHs (polycyclic aromatic hydrocarbons), cadmium, and welder were identified as having more than 5 connections within the network.

\section{Nano-materials}

Nanomaterials can be introduced as emerging cancer risk factors; for example carbon nanotubes and endocrine disruptor components (EDCs) [63]. Some types of carbon nanotubes may cause effects similar to asbestos. A longterm animal study showed that internal injection of all studied Nano materials including black carbon, aluminum oxide, aluminum silicate, titanium dioxide and amorphous silicon dioxide resulted to tumors formation. Nanomaterial power was also calculated to be 5 to 10 times higher than other materials [59].

\section{Biological agents}

Biologic agents can cause cancer development via direct effect (such as hepatitis) or toxic substances (such as aflatoxins, one of the most powerful toxins) [64]. Chronic $\mathrm{B}$ and $\mathrm{C}$ hepatitis virus infection can progress to severe long term liver damage such as cirrhosis and hematocritin. In 2000, 656,000 Hepatitis B virus infections in health care workers was reported to be developed due to injuries caused by contaminating activities; And about 16,400 hepatitis $\mathrm{C}$ infections have included about $40 \%$ of all infections in health care workers. HIV can also be an occupational transmitted agent, and it has been estimated that in 2000, 1,000 HIV infection cases occurred in health care workers. HIV opportunistic infections include cancers such as Kaposi-sarcoma and lymphoma [65]. Some infectious agents, such as Helicobacter pylori (gastric cancer), can be transmitted through contaminated water or food [66].

\section{Ionizing radiation}

Table 1. Agents that Cause Occupational Cancer in Different Industries

\begin{tabular}{|c|c|c|}
\hline Cancer & Source & Examples of Occupations \\
\hline Bladder & $\begin{array}{l}\text { Benzidine, beta-naphthylamine, } \\
\text { 4-aminobiphenyl, arsenic }\end{array}$ & $\begin{array}{l}\text { Rubber, leather, paving, roofing, printing and textile } \\
\text { industries; paint/dyeing products; chimney sweeping; } \\
\text { machinists; hairdressers and barbers; truck drivers }\end{array}$ \\
\hline Kidney & Cadmium, trichloroethylene, herbicides, wood dust & $\begin{array}{l}\text { Painting; metalworking; petroleum, plastics, and textile } \\
\text { industries }\end{array}$ \\
\hline Larynx & Asbestos, wood dust, paint fumes & $\begin{array}{l}\text { Metal working; petroleum, rubber, plastics, and textile } \\
\text { industries }\end{array}$ \\
\hline Leukemia & Formaldehyde, benzene, ethylene oxide, pesticides & Rubber manufacturing; oil refining; shoemaking \\
\hline Liver & Arsenic, vinyl chloride, aflatoxins & Plastic manufacturing \\
\hline Lung & $\begin{array}{l}\text { Radon, secondhand smoke, asbestos, arsenic, cadmium, } \\
\text { chromium compounds, diesel exhaust, sulfur mustard }\end{array}$ & $\begin{array}{l}\text { Rubber manufacturing, paving, } \\
\text { roofing, painting, chimney sweeping, } \\
\text { iron and steel foundry work, welding }\end{array}$ \\
\hline Lymphoma & $\begin{array}{l}\text { Benzene, 1, 3-butadiene, ethylene oxide, herbicides, } \\
\text { insecticides }\end{array}$ & Rubber manufacturing, painting, hairdresser or barber \\
\hline Mesothelioma & Asbestos & $\begin{array}{l}\text { Mining, railroad, automotive, plumbing, painting and } \\
\text { construction industries; factory workers }\end{array}$ \\
\hline Nasal cavity and sinus & $\begin{array}{l}\text { Mustard gas, nickel dust, chromium dust, leather dust, } \\
\text { wood dust, radium }\end{array}$ & $\begin{array}{l}\text { Textile and baking industry, flour } \\
\text { milling, nickel refining, furniture and } \\
\text { cabinet builders, shoemaking }\end{array}$ \\
\hline Skin & Arsenic, coal tars, paraffin, certain oils, sunlight & $\begin{array}{l}\text { Chimney sweeping; outside jobs that involve a lot of sun } \\
\text { exposure }\end{array}$ \\
\hline
\end{tabular}




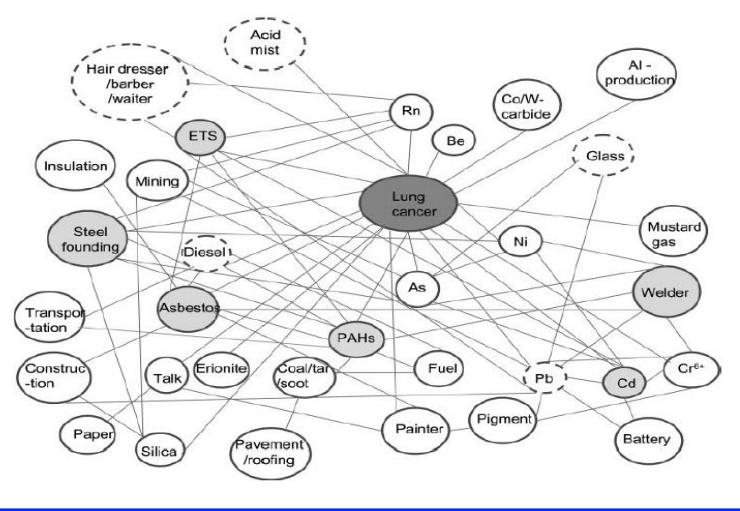

Figure 2. Exposure Network of Occupation- and Environment- induced Lung Cancer

Ionizing radiation can cause lethal mutations [35]. $\mathrm{X}$-ray is the most well-known ionizing radiation [67]. Nowadays, the use of ionizing radiation has spread, such as rays from radioactive decay, cosmic rays, etc. [68].

\section{Non ionizing radiation}

There are many documents show that non-ionizing radiation can cause cancer [69]. For many years, the cancer-causing effect of non-ionizing radiation has been the subject of scientific research. Clapp and colleagues in 2007 explained their new documents regarding environmental and occupational causes of cancer [70]. Ultraviolet Radiation (UVR) of sunlight or artificial sources (such as welding) can cause skin cancer [71]. Exposure to arc welding is associated with an increased risk of eye melanoma [72]. IARC has mentioned this type of radiation in relevant publications (IARC, 2012b) [59]. Other sources of artificial light radiation include the use of sunlight for tanning and solar lamps, as well as exposure to fluorescent lamps at workplace [73].

\section{Heat shock}

There are evidences that heat shock leads to damage to Deoxyribonucleic acid [74], which ultimately leads to cancer [75]. Heat shock may occur in furnace workers and melting operators in casting industries and so on [76].

\section{Work shift}

Work shift causes daily disorders, which were evaluated for the first time in 2007, and now, as an oncogene agent may be listed by IARC [77]. Workers of shift works may suffer from a rhythm of sleep and awakening and a lack of melatonin [78]. Exposure to light at night causes disturbances in the circadian cycle, possibly due to the combination of melatonin and clock genes, as an important factor in the development of breast cancer [77-78].

\section{Stress}

Work-related stress may indirectly lead to cancer, as workers may use coping strategies that include smoking and drug use. In 2003, Fox in his study concluded that stress, regardless of the type, severity or duration of exposure, has little effect on the incidence of cancer
[59]. However, few studies have performed to reach any conclusion - even basic- about stress causing factors. However, strong social support may reduce the incidence [79]. However, it should be noted that as stress may increase smoking, drinking, eating or consuming narcotic drugs, could enhance the risk of cancer [80].

\section{Sedentary work}

Boyle et al. performed a case-based study and on a population of colorectal cancer patients at West Australia in 2005 to 2007 , and found that long-term sedentary work may increase the risk of colon cancer and rectal cancer [81]. A research that has performed using recorded data showed an increased risk of testicular cancer for office workers [82]. Researchers have described the socio-economic status and lifestyle that is without mobility as two main causes of this type of cancer [83]. However, the incomplete occupational data, and the difficulty in finding an appropriate control group for comparing, are the main challenges in assessing these risk factors [84-85]. A part of 256,000 cases of liver, colon, and rectal cancers which are caused by lack of physical activity, can be prevented through transportation policies to encourage biking and walking [57-86].

\section{Environmental cancer}

The WHO defines the environment as "all the physical, chemical and biological factors external to the human host, and all related behaviors, but excluding those natural environments that cannot reasonably be modified". This definition is actually limited to those parts of the environment that can be controlled, including environmental health impacts such as air, water and soil pollution, electromagnetic fields, occupational, agriculture, behavior and lifestyle hazards (such as alcohol and tobacco consumption, diet, Personal habits and behaviors related to the social and cultural environment) which can be controlled [86]. Therefore, environmental interventions such as elimination or reduction of exposure to oncogene agents in the environment are key to reduce the incidence of cancer-related mortality [66]. The patterns of environmental pollution and the diseases that cause it in the country are very different, and national income and development levels appear to be main responsible for these differences [5]. The most important environmental cancer risk factors are described below:

\section{Sunlight}

One of the main environmental causes of cancer is natural radiation, including the sun [87]. The cause of most skin cancers is prolonged exposure to the sun [88]. The mortality due to ultraviolet radiation in 2000 were estimated approximately 60,000 people, of which 48,000 were melanoma and 12,000 others had scaled skin cancer [89]. Surdu and colleagues performed a study on the effect of UV exposure occupational protection, and found that its results were completely unexpected and limited to people with light skin [74]. 
Air pollution

Air pollution caused 108,000 deaths due to lung cancer in 2009 [57]. Solid fuel, which is used for more than half of the population in developing countries for cooking and heating, created 36,000 mortality from lung cancer [57-90]. Second-hand smoke has resulted in 21,000 mortality due to lung cancer [91]. This was the second most common environmental oncogene in the Europe Union. It is estimated that lung oncogene factors (such as arsenic, asbestos, beryllium, cadmium, chromium, etc.) caused to 111,000 deaths due to lung cancer [57].

\section{Radon}

Environmental risk factors are main factors that are related to cancer, but internal radon plays a decisive role in the causes of cancer in China [92]. Radon is related to the progression of lung cancer [93]. Many of biohazardous agents are related to life style that is also controllable [94]. Radon is the second important factor in lung cancer in many countries, so that $3-14 \%$ of all lung cancers (equal to 70-220 million mortality) is determined regarding to Radon mean level in a country [95].

On the other side, gradually, with the increase in the world's population, factors associated with lifestyle (tobacco use, vitality, unhealthy diets, etc.) have become very important [96]. The most important risk factors related to life style are:

\section{Cigarette smoking}

It has been proved that smoking increases the chance of cancer development, so reduction or contradiction with smoking, may decrease the chance of cancer development. Smoking is one of the main causes of lung cancer worldwide [16]. 85\% of cases of lung cancer in men are related to smoking [97]. In 2004, lung cancer includes $18 \%$ of all types of cancers, of which 938,000 mortality (71\%) were related to smoking [57]. In the past years, 17 countries of Europe Union have introduced laws to ban cigarette smoke in public places [59].

\section{Nutrition}

Nutrition and diet style is another important risk factor for cancer. The type of nutrients, which is consumed, varies according to geographic regions [98]. Approximately 200 studies have examined the relationship between fruit and vegetable intake and cancers of lung, colon, breast, cervix, esophagus, oral cavity, stomach, bladder, pancreas and ovaries. Consumption of fruits and vegetables has shown a significant protective effect, so that people who consume little fruit and vegetable (at least a quarter of the usual) have a two-fold increase in the risk of cancer [99]. Salt consumption is also highly related to mortality from stomach cancer and brain stroke [100].

\section{Social and economic status}

The socio-economic status (and, therefore, probably lifestyle) is described as a risk factor for skin melanoma. Martinsen et al. assessed the diversity in the prevalence of skin melanoma, in five North African countries regarding occupation and socioeconomic status. They compared the data of occupation of 15 million workers to the recorded national mortality. The highest risk was found in dentists, while the risk was increased in managers. The least risk was found in anglers and all non-expert workers also had a lower risk [59].

In conclusion, the data presented in this report shows that exposure to environmental harmful factors is one of the major causes of illness, death and disability worldwide [5-96]. Almost one third of all cancers can be prevented [34]. More than $75 \%$ of mortality due to cancer can be prevented by avoiding risk factors such as: tobacco, overweight /obesity, inadequate diet, physical inactivity, alcohol, sexually transmitted infections, and air pollution [101]. Most of caused by environmental, occupational or non-genetic factors, and are potentially preventable [92]. Because of the sharp increase in the incidence of occupational and environmental cancers, there is a strong need for planning and performing scientific interventions, to minimize the thousands of deaths due to occupational cancer [19]. The health consequences of exposure to environmental harmful agents are major and growing problems, but enough attention has not been paid to them; and it is now the time to pay a global attention to the big problem of environmental pollution problem [5]. It's the time to determine numerical and applicable targets for pollution control. Therefore, the world's response to pollution requires the same degree of difficulty that is performed for AIDS, tuberculosis and malaria. The international community's focus on environmental pollution can save millions lives [5-102]. The incidence of cancers varies between different countries; so, cancer control programs should be relied on the prevalence of cancer in each country [96]. For example, the prevalence of cancer in Asian countries is very diverse due to the great difference in lifestyle [26]. With industrial progress and economic development, air quality in Asian countries has become worse than past, and air pollution in open air has become a concern. For example, levels of Polycyclic Aromatic Hydrocarbons (PAHs) in large Asian large cities, is higher than western countries [103]. Income and developmental level are the main factors for determination of various patterns of environmental pollution and disease [28]. Therefore, research in less developed countries is required, as each country faces unique challenges in which, there is a cultural, political and economic context [104]. Programs of improving public health and environmental protection are required in all countries at every levels of economic development, and pollution control strategies and technologies that have been successfully developed in developed countries should be transferred to low-income and middle-income countries [5]. Personal protective equipment, engineering and management controls Preventing workplace exposure and employee training, can prevent exposure to oncogenes in the workplace [105]. The prevention of global cancer is an important goal for its application to large populations via promotion of performance and predicted health behaviors, effectiveness and affordability for all socioeconomic groups [37]. Twenty-five years ago, the European Union introduced its first global instruction to improve cancer 
prevention at the workplace, which at that time the modern law was an important help for protecting workers [10]. For many stakeholders, it's time to adapt laws and policies to new knowledge and emerging risks. It is assumed that occupational and environmental cancers can be eliminated, and this can save many people's lives and significantly is related to overall health. Through the Monographs program, IARC wants to prevent occupational and environmental cancers [106]. On the other hand, all the environmental factors of the cancer, including the background radiation of the sun, can not be controlled, and they cause cancer through inherited genetic disorders. In the future, developing gene modification techniques may serve as preventative measures [39]. For detection of cancer preventative chances in occupational environment, the most common causes of cancer s should be identified, and the relationship between exposure to the agent and development of cancer, should be determined by estimating the risks of exposure to a certain level of exposure. But the important point is that exposure to less than the limit range of oncogenic agents, is one of the most important concerns due to the lack of exposure information (including the duration and number of unexpected exposures and the number of people who may be exposed) [66]. Therefore, quantitative risk assessment is a very important step for making decision in this field [32, 107-108]. To reduce the risk of cancer in workers, preventative strategies should be used at high-risk working environments [13]. Effective Prevention of Occupational Cancer requires knowledge of oncogenes. Professional health is influenced by IT solutions to improve prevention, early diagnosis, treatment, and, ultimately, efficacy and preventative systems. So, IT solutions are important health care issues. Occupational cancer information is important for policy makers, managers, doctors, patients, and researchers, in information systems. Since, information about occupational cancers and their causes can determine labor groups that require special attention. For example, workers exposed to harm can be assessed and considered for preventive interventions [34, 109]. Other steps should be taken include: reducing tobacco use, controlling respiratory infectious diseases, and replacing inefficient energy sources with renewable energy sources [104]. In order to assess future occupational cancer, further researches should be focused on assessment of lifestyle factors in occupational environments [94]. So, it is recommended that more studies to be performed in this field to not only determine the number and type of cancers due to occupational and environmental risk factors, but also effective scientific and their preventative methods could be determined.

\section{References}

1. Brunekreef B, Holgate ST. Air pollution and health. The lancet. 2002;360(9341):1233-42.

2. Kampa M, Castanas E. Human health effects of air pollution. Environmental pollution. 2008;151(2):362-7.

3. Cohen AJ, Ross Anderson H, Ostro B, Pandey KD, Krzyzanowski M, Künzli N, et al. The global burden of disease due to outdoor air pollution. Journal of Toxicology and Environmental Health, Part A. 2005;68(13-14):1301-7. 4. Sly PD, Carpenter DO, Van den Berg M, Stein RT, Landrigan PJ, Brune-Drisse M-N, et al. Health consequences of environmental exposures: causal thinking in global environmental epidemiology. Annals of global health. 2016;82(1):3-9.

5. Landrigan PJ, Sly JL, Ruchirawat M, Silva ER, Huo X, Diaz-Barriga F, et al. Health consequences of environmental exposures: changing global patterns of exposure and disease. Annals of global health. 2016;82(1):10-9.

6. Ferlay J, Parkin D, Steliarova-Foucher E. Estimates of cancer incidence and mortality in Europe in 2008. European journal of cancer. 2010;46(4):765-81.

7. Society AC. Cancer facts \& figures: The Society; 2008.

8. Boyle P, Levin B. World cancer report 2008: IARC Press, International Agency for Research on Cancer; 2008.

9. Organization WH. National cancer control programmes: policies and managerial guidelines: World Health Organization; 2002.

10. Takala J. Eliminating occupational cancer in Europe and globally. 2015.

11. Fritschi L, Driscoll T. Cancer due to occupation in Australia. Australian and New Zealand journal of public health. 2006;30(3):213-9.

12. (ASCC) ASaCC. OCCUPATIONAL CANCER IN AUSTRALIA. Australian Safety and Compensation Council. 20062006.

13. Yari S, Fallah AA, Varmazyar S. Assessment of semiquantitative health risks of exposure to harmful chemical agents in the context of carcinogenesis in the latex glove manufacturing industry. Asian Pacific journal of cancer prevention: APJCP. 2015;17:S3.

14. Egeghy PP, Vallero DA, Hubal EAC. Exposure-based prioritization of chemicals for risk assessment. Environmental science \& policy. 2011;14(8):950-64.

15. IARC. AGENTS CLASSIFIED BY THE IARC MONOGRAPHS, VOLUMES 1-122. 2018;1-122.

16. Mosavi-Jarrahi A, Mohagheghi M, Yazdizadeh B, Kolahi A, Tahmasebi S, Sharifi S. Analysis of smoking behaviour among Iranian population: a cohort and period analysis. Asian Pacific journal of cancer prevention: APJCP. 2004;5(1):66-9.

17. IARC. GLOBOCAN 2012.

18. Takala J, Hämäläinen P, Saarela KL, Yun LY, Manickam $\mathrm{K}$, Jin TW, et al. Global estimates of the burden of injury and illness at work in 2012. Journal of occupational and environmental hygiene. 2014;11(5):326-37.

19. Shrivastava SR, Shrivastava PS, Ramasamy J. Occupational cancer: Public health interventions to minimize its burden and impact on the society. Iranian journal of cancer prevention. 2014;7(2):111.

20. Takala J, editor Introductory report: decent work-safe work. XVIth World Congress on Safety and Health at Work; 2002: International Labour Office, Vienna.

21. Kogevinas M, Kauppinen T, Boffetta P, Saracci R. Estimation of the burden of occupational cancer in Europe. Final report to the European Commission of a project funded by the programme" Europe Against Cancer"'(Contract SOC 96200742 05F02) Barcelona: IMIM. 1998.

22. Straif K. The burden of occupational cancer. Occupational and environmental medicine. 2008;65(12):787-8.

23. Mohagheghi MA, Mousavi-Jarrahi Y, Mosavi-Jarrahi A. Cost of care for lung cancer in the first year after diagnosis in Iran. Asian Pac J Cancer Prev. 2011;12(4).

24. Mosavi-Jarrahi A, Mohagheghi M, Kalaghchi B, MousaviJarrahi Y, Noori MK. Estimating the incidence of lung cancer attributable to occupational exposure in Iran. Population 
health metrics. 2009;7(1):7.

25. Ferlay J. GLOBOCAN 2008 v1. 2, Cancer incidence and mortality world-wide: IARC Cancer Base No. 10. http:// globocan iarc. 2010.

26. Park S, Bae J, Nam B-H, Yoo K-Y. Aetiology of cancer in Asia. Asian Pac J Cancer Prev. 2008;9(3):371-80.

27. Abdirad A, Ghaderi-Sohi S, Shuyama K, Koriyama C, Nadimi-Barforoosh H, Emami S, et al. Epstein-Barr virus associated gastric carcinoma: a report from Iran in the last four decades. Diagnostic Pathology. 2007;2(1):25.

28. Boffetta P, Islami F. Cancer in Low- and MediumIncome Countries. Annals of Global Health. 2014 2014/09/01/;80(5):345.

29. Brown JR, Thornton JL. Percivall Pott (1714-1788) and chimney sweepers' cancer of the scrotum. British journal of industrial medicine. 1957;14(1):68.

30. Bowman JD, Touchstone JA, Yost MG. A populationbased job exposure matrix for power-frequency magnetic fields. Journal of occupational and environmental hygiene. 2007;4(9):715-28.

31. Normohammadi M, Kakooei H, Omidi L, Yari S, Alimi R. Risk assessment of exposure to silica dust in building demolition sites. Safety and health at work. 2016;7(3):251-5.

32. Yari S. Inherent safety design in compose of urban gas station. Safety Promotion and Injury Prevention. 2015;3(2):135-40.

33. Balamuralikrishnan B, Balachandar V, Kumar SS, Stalin N, Varsha P, Devi SM, et al. Evaluation of chromosomal alteration in electrical workers occupationally exposed to low frequency of electro magnetic field (EMFs) in Coimbatore population, India. Asian Pacific Journal of Cancer Prevention. 2012;13(6):2961-6.

34. Davoodi S, Safdari R, Ghazisaeidi M, Mohammadzadeh Z, Azadmanjir Z. Prevention and early detection of occupational cancers-a view of information technology solutions. Asian Pacific journal of cancer prevention: APJCP. 2015;16(14):5607.

35. Muirhead C, Haylock R. Ionising radiation and occupational cancer in Britain. British journal of cancer. 2012;107(9):1660.

36. Rushton L, Hutchings SJ, Straif K. Occupational Cancer Burden. Occupational Cancers: Springer; 2014. p. 531-50.

37. Sauter SL, Murphy LR, Hurrell JJ. Prevention of workrelated psychological disorders: A national strategy proposed by the National Institute for Occupational Safety and Health (NIOSH). American Psychologist. 1990;45(10):1146.

38. Boffetta P. Epidemiology of environmental and occupational cancer. Oncogene. 2004;23(38):6392.

39. Loomis D, Grosse Y, Lauby-Secretan B, El Ghissassi F, Bouvard V, Benbrahim-Tallaa L, et al. The carcinogenicity of outdoor air pollution. The lancet oncology. 2013;14(13):12623.

40. Boffetta P, Jourenkova N, Gustavsson P. Cancer risk from occupational and environmental exposure to polycyclic aromatic hydrocarbons. Cancer Causes \& Control. 1997;8(3):444-72.

41. Fritschi L. Shift work and cancer. BMJ: British Medical Journal (Online). 2009;339.

42. Stevens RG, Hansen J, Costa G, Haus E, Kauppinen T, Aronson KJ, et al. Considerations of circadian impact for defining 'shift work'in cancer studies: IARC Working Group Report. Occupational and environmental medicine. 2010:oem. 2009.053512.

43. Megdal SP, Kroenke CH, Laden F, Pukkala E, Schernhammer ES. Night work and breast cancer risk: a systematic review and meta-analysis. European Journal of Cancer. 2005;41(13):2023-32.

44. Silverman DT, Levin LI, Hoover RN, Hartge P. Occupational risks of bladder cancer in the United States: I. White men. JNCI: Journal of the National Cancer Institute. 1989;81(19):1472-80.

45. McCredie M, Stewart JH. Risk factors for kidney cancer in New South Wales. IV. Occupation. British Journal of Industrial Medicine. 1993;50(4):349-54.

46. Chow W-H, Dong LM, Devesa SS. Epidemiology and risk factors for kidney cancer. Nature Reviews Urology. 2010 05/01/online; 7:245.

47. Muscat JE, Wynder EL. Tobacco, alcohol, asbestos, and occupational risk factors for laryngeal cancer. Cancer. 1992;69(9):2244-51.

48. Guénel P, Imbernon E, Chevalier A, Crinquand-Calastreng A, Goldberg M. Leukemia in relation to occupational exposures to benzene and other agents: A case-control study nested in a cohort of gas and electric utility workers. American Journal of Industrial Medicine. 2002;42(2):87-97.

49. Stemhagen A, Slade J, Altman R, Bill J. OCCUPATIONAL RISK FACTORS AND LIVER CANCERA RETROSPECTIVE CASE-CONTROL STUDY OF PRIMARY LIVER CANCER IN NEW JERSEY. American Journal of Epidemiology. 1983;117(4):443-54.

50. Brüske-Hohlfeld I, Mühner M, Pohlabeln H, Ahrens W, Bolm-Audorff U, Kreienbrock L, et al. Occupational Lung Cancer Risk for Men in Germany: Results from a Pooled Case-Control Study. American Journal of Epidemiology. 2000;151(4):384-95.

51. Brownson RC, Reif JS. A Cancer Registry-Based Study of Occupational Risk for Lymphoma, Multiple Myeloma and Leukaemia. International Journal of Epidemiology. 1988;17(1):27-32.

52. Malker HSR, McLaughlin JK, Malker BK, Stone BJ, Weiner JA, Erickson JLE, et al. Occupational Risks for Pleural Mesothelioma in Sweden, 1961-79. JNCI: Journal of the National Cancer Institute. 1985;74(1):61-6.

53. Vaughan TL, Strader C, Davis S, Daling JR. Formaldehyde and cancers of the pharynx, sinus and nasal cavity: I. Occupational exposures. International Journal of Cancer. 1986;38(5):677-83.

54. Gawkrodger DJ. Occupational skin cancers. Occupational Medicine. 2004;54(7):458-63.

55. Vainio H, Zendehdel K. Occupational/Environmental Cancer at the International Congress on Cancer prevention \& Early Detection: A Workshop Report. 2018. 2018 201804-07;9(4):5. Epub 2018-04-07.

56. Neumann V, Löseke S, Nowak D, Herth FJ, Tannapfel A. Malignant pleural mesothelioma: incidence, etiology, diagnosis, treatment, and occupational health. Deutsches Ärzteblatt international. 2013;110(18):319.

57. WHO J. Global health risks: mortality and burden of disease attributabbl to selected major risk. Geneva: WHO; 2009.

58. Yang M. A current global view of environmental and occupational cancers. Journal of Environmental Science and Health, Part C. 2011;29(3):223-49.

59. Lissner L, Kuhl K, Knaupinen T, Uuksulainen S. Exposure to carcinogens and work-related cancer: A review of assessment methods. European Risk Observatory Report; European Agency for Safety and Health at Work: Luxembourg. 2014:1-64.

60. Bergman Á, Heindel JJ, Jobling S, Kidd KA, Zoeller RT. State of the science of endocrine disrupting chemicals 2012: an assessment of the state of the science of endocrine disruptors prepared by a group of experts for the United Nations Environment Programme and World Health Organization: World Health Organization; 2013.

61. Kampa M, Hatzoglou A, Notas G, Damianaki A, Bakogeorgou E, Gemetzi C, et al. Wine antioxidant polyphenols inhibit the proliferation of human prostate cancer cell lines. Nutrition 
and cancer. 2000;37(2):223-33.

62. McLarty J, Bigelow RL, Smith M, Elmajian D, Ankem M, Cardelli JA. Tea polyphenols decrease serum levels of prostate-specific antigen, hepatocyte growth factor, and vascular endothelial growth factor in prostate cancer patients and inhibit production of hepatocyte growth factor and vascular endothelial growth factor in vitro. Cancer prevention research. 2009:1940-6207. CAPR-08-0167.

63. Kuempel E, Castranova V, Geraci C, Schulte P. Development of risk-based nanomaterial groups for occupational exposure control. Journal of Nanoparticle Research. 2012;14(9):1029.

64. Heederik D. Endotoxins: An emerging biological risk. Endotoksini: nastajajoče biološko tveganje. 2007.

65. Prüss-Üstün A, Rapiti E, Hutin Y. Estimation of the global burden of disease attributable to contaminated sharps injuries among health-care workers. American journal of industrial medicine. 2005;48(6):482-90.

66. Organization WH. An overview of the evidence on environmental and occupational determinants of cancer. Asturias, Spain. 2011:1.

67. Brenner DJ, Doll R, Goodhead DT, Hall EJ, Land CE, Little $\mathrm{JB}$, et al. Cancer risks attributable to low doses of ionizing radiation: assessing what we really know. Proceedings of the National Academy of Sciences. 2003;100(24):13761-6.

68. Gofman JW. Radiation and human health. 1981.

69. Humans IWGotEoCRt, Organization WH, Cancer IAfRo. Non-ionizing Radiation: Static and extremely lowfrequency (ELF) electric and magnetic fields: World Health Organization; 2002.

70. Clapp RW, Jacobs MM, Loechler EL. Environmental and occupational causes of cancer: new evidence 2005-2007. Reviews on environmental health. 2008;23(1):1-38.

71. De Gruij1 F. Skin cancer and solar UV radiation. European Journal of Cancer. 1999;35(14):2003-9.

72. Currie A. Welding and non-melanoma skin cancer. Clinical and experimental dermatology. 2000;25(1):28-9.

73. Ng K-H, editor Non-ionizing radiations-sources, biological effects, emissions and exposures. Proceedings of the international conference on non-ionizing radiation at UNITEN; 2003.

74. Surdu S, Fitzgerald EF, Bloom MS, Boscoe FP, Carpenter DO, Haase RF, et al. Occupational exposure to ultraviolet radiation and risk of non-melanoma skin cancer in a multinational European study. PLoS One. 2013;8(4):e62359.

75. Cairns J, editor The possible prevention of cancer. Environmental Health; 2011: BioMed Central.

76. Xu Z, Pan GW, Liu LM, Brown LM, Guan DX, Xiu Q, et al. Cancer risks among iron and steel workers in Anshan, China, Part I: Proportional mortality ratio analysis. American journal of industrial medicine. 1996;30(1):1-6.

77. Straif K, Baan R, Grosse Y, Secretan B, El Ghissassi F, Bouvard V, et al. Carcinogenicity of shift-work, painting, and fire-fighting. The lancet oncology. 2007;8(12):1065-6.

78. Cancer IAfRo. Painting, firefighting, and shiftwork: IARC Press, International Agency for Research on Cancer; 2010.

79. Cohen S, Wills TA. Stress, social support, and the buffering hypothesis. Psychological bulletin. 1985;98(2):310.

80. Eysenck HJ. Smoking, personality, and stress: Psychosocial factors in the prevention of cancer and coronary heart disease: Springer Science \& Business Media; 2012.

81. Boyle T, Fritschi L, Heyworth J, Bull F. Long-term sedentary work and the risk of subsite-specific colorectal cancer. American journal of epidemiology. 2011;173(10):1183-91.

82. Yousif L, Hammer GP, Emrich K, Blettner M, Zeeb H. Occupational risk factors for testicular cancer: a registrybased case-control study in Rhineland Palatinate-Germany.
GMS German Medical Science. 2013;11.

83. VENA JE, GRAHAM S, ZIELEZNY M, SWANSON MK, BARNES RE, NOLAN J. Lifetime occupational exercise and colon cancer. American Journal of Epidemiology. 1985;122(3):357-65.

84. Le Marchand L, Wilkens LR, Kolonel LN, Hankin JH, Lyu L-C. Associations of sedentary lifestyle, obesity, smoking, alcohol use, and diabetes with the risk of colorectal cancer. Cancer research. 1997;57(21):4787-94.

85. yari s. Evaluation Quantitative (LPD) and Qualitative (NMQ) musculoskeletal disorders of workers and its relationship with the body mass index (BMI (in a paper making industry in 2015. Iran Occupational Health. 2016;13(5):88-97.

86. Prüss-Üstün A, Corvalán C. Preventing disease through healthy environments. Towards an estimate of the environmental burden of disease Geneva: World Health Organization. 2006.

87. Setlow RB. The wavelengths in sunlight effective in producing skin cancer: a theoretical analysis. Proceedings of the National Academy of Sciences. 1974;71(9):3363-6.

88. Brash D, Ziegler A, Jonason A, Simon J, Kunala S, Leffell $\mathrm{D}$, editors. Sunlight and sunburn in human skin cancer: p53, apoptosis, and tumor promotion. The journal of investigative dermatology Symposium proceedings; 1996.

89. Dayan A. Solar and Ultraviolet Radiation. IARC Monographs on the Evaluation of Carcinogenic Risks to Humans. Vol 55. Journal of clinical pathology. 1993;46(9):880.

90. Cancer IAfRo. Household use of solid fuels and hightemperature frying: IARC Press, International Agency for Research on Cancer; 2010.

91. Oberg M, Jaakkola M, Prüss-Üstün A, Peruga A, Woodward A, Organization WH. Global estimate of the burden of disease from second-hand smoke. 2010.

92. Li P, Deng S-S, Wang J-B, Iwata A, Qiao Y-L, Dai X-B, et al. Occupational and environmental cancer incidence and mortality in China. Occupational medicine. 2012;62(4):2817.

93. Darby S, Whitley E, Silcocks P, Thakrar B, Green M, Lomas $\mathrm{P}$, et al. Risk of lung cancer associated with residential radon exposure in south-west England: a case-control study. British Journal of cancer. 1998;78(3):394.

94. Higginson J. Importance of environmental and occupational factors in cancer. Journal of Toxicology and Environmental Health, Part A Current Issues. 1980;6(5-6):941-52.

95. Ting DSK. WHO handbook on indoor radon: a public health perspective. Taylor \& Francis; 2010.

96. Roshandel G, Boreiri M, Sadjadi A, Malekzadeh R. A diversity of cancer incidence and mortality in West Asian populations. Annals of global health. 2014;80(5):346-57.

97. Matos E, Vilensky M, Boffetta P. Environmental and occupational cancer in Argentina: a case-control lung cancer study. Cadernos de saude publica. 1998;14:S77-S86.

98. Thorburn AN, Macia L, Mackay CR. Diet, metabolites, and "western-lifestyle" inflammatory diseases. Immunity. 2014;40(6):833-42.

99. Block G, Patterson B, Subar A. Fruit, vegetables, and cancer prevention: A review of the epidemiological evidence. Nutrition and Cancer. 1992 1992/01/01;18(1):1-29.

100. Joossens JV, Geboers J. Diet and carcinogenesis. Nutrition and Cancer. 1981 1981/01/01;2(4):250-61.

101. Anand P, Kunnumakara AB, Sundaram C, Harikumar KB, Tharakan ST, Lai OS, et al. Cancer is a preventable disease that requires major lifestyle changes. Pharmaceutical research. 2008;25(9):2097-116.

102. Friedenreich CM. Physical activity and cancer prevention: from observational to intervention research. Cancer 
Epidemiology and Prevention Biomarkers. 2001;10(4):287301.

103. Chen B, Hong C, Kan H. Exposures and health outcomes from outdoor air pollutants in China. Toxicology. 2004;198(1-3):291-300.

104. Hashim D, Boffetta P. Occupational and environmental exposures and cancers in developing countries. Annals of global health. 2014;80(5):393-411.

105. Yari S, Pouyakian M, Jafari MJ, Alipour A, Varmazyar S. Preparation and psychometry of a safety assessment questionnaire for urban gas stations. Safety Promotion and Injury Prevention. 2018;5(3):169-80.

106. Smith RA. Expert Group: IARC Handbooks of Cancer Prevention. Vol. 7: Breast Cancer Screening. Lyon, France: IARC; 2002. 248pp. Breast Cancer Research. 2003;5(4):216.

107. Yari S, Akbari H, Gholami Fesharaki M, Khosravizadeh O, Ghasemi M, Barsam Y, et al. Developing a model for hospital inherent safety assessment: Conceptualization and validation. International Journal of Risk \& Safety in Medicine. 2018 (Preprint):1-12.

108. Yari S. Assessment of potential risk by the failure mode and effects analysis in an air conditioning equipment manufacturing company. Safety Promotion and Injury Prevention. 2017;5(2):89-96.

109. Feder IS, Theile A, Tannapfel A. Histological findings and lung dust analysis as the basis for occupational disease compensation in asbestos-related lung cancer in Germany. International journal of occupational medicine and environmental health. 2018;31(3):293-305.

c) (i) (3)

This work is licensed under a Creative Commons AttributionNon Commercial 4.0 International License. 